\title{
English Teaching and Learning in Brazilian Regular Schools and Language Schools: A Study on Teachers' Beliefs
}

\author{
Carina Silva Fragozo ${ }^{1} \&$ Mônica Deitos Stedile Monawar ${ }^{1}$ \\ ${ }^{1}$ Department of Linguistics, Pontifical Catholic University of Rio Grande do Sul, Porto Alegre, Brazil \\ Correspondence: Carina Silva Fragozo, Department of Linguistics, Pontifical Catholic University of Rio Grande \\ do Sul, Porto Alegre, Brazil. E-mail: cfragozo@gmail.com
}

Received: May 2, 2012

Accepted: May 28, 2012

Online Published: August 27, 2012

doi:10.5539/jel.v1n2p82

URL: http://dx.doi.org/10.5539/jel.v1n2p82

\begin{abstract}
This paper aims to diagnose, through a qualitative comparative study, the main differences concerning the teaching of English in Brazilian regular schools when compared to language schools. There has been a growing tendency of students to attend language schools while still having English classes at their regular schools, and this has led to a lot of change in teachers' beliefs and approaches in general over the years. To establish this diagnosis, a questionnaire consisting of 14 key points related to this topic (ranging from teaching resources and methodologies to workloads and knowledge of grammar) was answered by six teachers of English, three working at regular schools, and three at language schools. The main findings can be summarized by the fact that heavier workloads, bigger groups, lack of resources and focus on reading and writing have made regular school teaching less effective than the experience students have when attending classes at language schools.
\end{abstract}

Keywords: English teaching, regular school, language school, teachers' beliefs

\section{Introduction}

Undoubtedly, English has achieved a very important position among other languages, as it is spoken in almost every country in the world, mainly by non-native speakers, and is considered a global language (Jenkins, 2003; Crystal, 2003). Even though our society agrees on the importance of learning foreign languages, English teaching and learning are generally considered insufficient in Brazilian regular schools.

This paper aims to uncover and analyze aspects of teaching of English in Brazilian regular schools (RS) as well as in language schools (LS), since for the past years the number of students looking for language schools while being in regular schools seems to have been constantly increasing. Would this movement be an indicator that there is something missing in the teaching of English in regular schools? Or perhaps would their objectives be so that only a language school would suffice? These and other questions arose frequently in teachers' meetings and university under and graduate courses. As an attempt to answer some of them, we develop this article in the following fashion: first, we propose a discussion of the main differences between regular schools and language schools, giving the reader enough data to move on to the next section, in which we formulate our working hypotheses and methodology of research. After that, we have the analyses of the answers to a questionnaire presented to teachers of regular schools as well as language schools, dividing them pedagogically according to the matter at hand-place of work, methodology, material used, and so on. A final discussion of the results found follows, as well as further references to the reader on the subject.

\subsection{Regular School X Language School}

As aforementioned, there seems to be an ever-growing gap between what is taught or learned in relation to the English language in regular schools and language schools in Brazil. However, in order to better understand where these differences could be coming from, a parallel needs to be established between the two types of institutions.

In order to characterize English teaching in Brazilian public schools, Coelho (2005) mentions three periods. The first one refers to the first half of the twentieth century, when the legislation emphasized the practical aspects of learning a foreign language but, as there was little time dedicated to the teaching of foreign languages and few prepared teachers, the practical aspects of knowing a foreign language were not applied. The consequence was uninteresting classes based on decontextualized grammar exercises and memorization of rules (Brasil 1999, p. 
26). The second period was around the 70's, when the Brazilian elite started to notice the importance of learning English. In this period, language schools started to appear all over the country and trips to the United States were more frequent. The third period refers to the moment when foreign language teaching became mandatory, according to the Lei de Diretrizes e Bases (Brazilian educational laws), established in 1996. Since then, the Ministry of Education does not decide that English is the foreign language taught, being the choice up to each school. Nevertheless, it is the main foreign language in the country.

The PCNs (Parâmetros Curriculares Nacionais), which are references for Elementary and High School teaching proposed by the Brazilian Ministry of Education, refer to this situation (Brasil 1998, p. 19):

Even though the knowledge of foreign languages is highly looked upon by society, these foreign languages, as subjects, find themselves out of place in schools. The dissemination of language schools is clear evidence for such affirmation. The teaching of these languages, as it happens in relation to other subjects, is the school's responsibility, and it is there that it should take place.

This preference for English as the foreign language to be studied in Brazil is made evident, according to Martins (2008, p. 195):

By the great amount of language institutes that offer English courses in Brazil we can notice how the language is being valued by the society, for it is remarkable that the whole world and, naturally, Brazil, are aware of the fact that to learn English is of vital importance in order for one to get in touch with the latest technological and scientific innovations, and that the ones who have a good grasp of the language have the advantage over the ones who do not.

This situation can be connected to certain parameters established by the federal government in which there is more focus on some skills related to the target language than on others. For example, the PCNs, according to Martins (2008, p. 198), "justify the teaching of reading in detriment of other abilities, due to few opportunities that the population has to use foreign languages as an instrument for oral communication, inside or outside the country [...]." These parameters go on specifying that the focus on teaching students how to develop their reading abilities in the foreign language could also serve other purposes, such as helping them overcome difficulties they may be facing in their own language when it comes to reading tasks, as well as preparing them for college admission exams, which focus on reading exercises. Consequently, the students who want or need to develop abilities such as oral communication as well as reading and writing seek the English courses as a solution to what has been lacking in regular schools.

Studies like Barcelos (2007), which analyzed narratives by students of Languages and Executive Secretariat about their experience in language learning in Brazil, show that the subjects consider the regular school and the language school as two totally different places. The narratives illustrate that in the language school it is possible to learn, but not in the regular school. In addition, most subjects describe English learning in public schools as "bad" and "not motivating". The reasons mentioned by the subjects are varied, but they usually highlight the emphasis on grammar aspects and teachers' inability to teach the language. The regular school, therefore, is seen as a place where the students' expectations are not met, whereas the language school is seen as an investment, as a place where you can really learn the language. This point of view is shown in the following excerpt, taken from Barcelos (2007, p. 159):

(...) I studied in a public school and I wouldn't really learn English there. So, I asked my father to pay an English course to me. He couldn't, but he did. In the English course, I really started learning. I wanted to go to class every day. I was in love with English.

Thus, the language school, in contrast to the regular school, is a place where there are no learning problems, and where the competence of the teachers is unquestioned (Barcelos 2007, p. 160).

The matter of competence on the teachers' part can be related to how their education or degrees are seen by their employers in general. Works such as Félix (2005), Araújo (2003), as well as news in newspapers and the federal government website have made even more noteworthy the disparities in terms of education between teaching staffs in regular schools and language schools. It is of common agreement that only the university undergraduate degree is not sufficient for today's demands on English teaching, no matter in what type of institution it takes place. The teacher needs to continue on improving their knowledge of the language in terms of usage as well as in terms of metalinguistic knowledge; keeping up to date with new teaching technologies as well as methods and researches that could improve their teaching experience, thus making their students have a better learning experience themselves.

The Ministry of Education released on its website a news article with the title Continuing education courses may 
help to improve the level of English teachers (2008), showing that the widespread concern for improving the education the teachers received prior to entering a classroom has been a topic of discussion for years in Brazil. The article consists of an interview with a professor of a private university in Sao Paulo, but with experience in teaching in regular schools as well as in language schools. She affirms that the ones who work with continuing education courses for English teachers know that colleges and universities - with few usual exceptions - are not graduating English teachers prepared to practice their jobs, not from the educational point of view, nor from a pragmatic one.

The point over which the article concludes is that seminars and isolated meetings do not help these teachers to improve their teaching practice. These continuing education courses are necessary in order to maintain a uniform, constant improvement, assuring the permanent progress made by the professionals of education in the country. Furthermore, information in this article pointed out that teachers of regular schools might not take these courses for reasons ranging from excessive workloads, too little free time, and other demands by their schools that are not related to their curriculum.

When interviewed by a newspaper from Rio de Janeiro (O Fluminense, 2001) about the advantages of working at a private language school, one of the teachers affirmed that the main advantages of working in a language school are the investments received by the teachers in terms of training courses, pedagogical follow-ups, promotion of workshops, courses and forums, also enriching the curriculum.

It seems that the difference in terms of how teachers' education is seen by different groups of institutions is abysmal. One other point of contrast is made regarding the teaching of children, and how this is approached by both regular schools and language schools. Regular schools, according to Tonelli and Cristóvão (2010), tend to rely only on the education the teacher received from the university course they have attended, a lot of the times not having particular pedagogical nor methodological knowledge related to teaching children. English courses, however, constantly seem to do pedagogical follow-ups and methodological training courses to adapt their teaching approaches to the target age group. When that does not take place inside the course, the teachers are able to look for such courses themselves and are motivated to do so, and later on share their findings with their colleagues. The fact that there is an enormous parcel of English teachers working in regular schools, the authors discuss that the curriculum of the undergraduate course in Languages should be reviewed, taking these special needs into consideration. After all, during the undergraduate courses might be the only time in which some of these teachers-to-be can have access to that type of knowledge.

Other problems related to foreign language teaching / learning in Brazilian regular schools have been widely discussed in the literature (Perin, 2003; Barcelos, 2007; Miccoli, 2007; Villani, 2008; Fragozo, 2011). Most studies refer to a number of challenges faced by teachers in this context, like the great number of students in class (usually from 30 to 50), lack of discipline, proficiency heterogeneity, motivation and status of the discipline.

Miccoli (2007), who investigated narratives by fourteen teachers in both public and private regular schools, found that one of the problems highlighted by the subjects was the use of teaching material like books, photocopies, dictionaries and CDs. When this material is available, it does not meet the teachers' expectations. When it is not available, the teacher has no alternative but writing the subjects on the blackboard for students to copy. Thus, according to the author, the role of teaching materials should be discussed, so that teachers do not feel stuck to the book or lost without it (p. 54).

Besides, the author points out that teachers from both public and private schools refer to the lower status of English in contrast to other disciplines. According to her, there are schools that value English teaching, but they are not the majority.

Finally, it seems mandatory to understand English teaching differently according to the multiple realities with which these teachers are faced. There are many points to be approached with a critical eye, such as the curriculums at Languages courses in colleges and universities that need to be reviewed in order to insert topics that might not be accessible to teachers after graduation; the fact that the workloads teachers are faced with do not motivate them nor give them the proper time to search for continuing education courses; the role that the institutions of work play in helping their own professionals to teach better, and finally, the ever-growing gap between regular schools and language schools must not be overlooked, once it affects teachers and students alike.

Considering the sources quoted in this article, it is necessary to point out that these differences regarding English teaching in regular schools and language schools are not a novelty to the government, to the institutions of work or to the teachers that have been dealing with it every day. However, it seems necessary to say more from the 
point of view of comparison, and how complementary some of these views and practices could be.

In the next section, hypotheses on how students and teachers alike perceive regular schools and language schools as two separate realities will be drawn and discussed further.

\subsection{Research Hypotheses / Aims}

Based on the discussion presented in 1.1, which shows that language schools and regular schools are seen as two totally different places by students (Barcelos, 2007) and teachers alike (Miccoli, 2007), this study aims at comparing the experience of teachers in both contexts.

Although there are studies that show the problems in regular schools, none of them apply the same questions to teachers both in regular schools and language schools.

The general hypothesis to be presented here is that, due to a number of factors from which we plan on addressing a few, language schools provide a better learning environment, as well as a better teaching environment, so that the result tends to be more effective learning and teaching in contexts connected to this type of institution. Consequently, we suppose that teachers in language schools are more valued by students.

Other secondary hypotheses inspired the inclusion of the 14 questions in the research. They are the following:

- Students are more motivated to learn English in language courses than in regular schools.

- Classes in language courses usually integrate the four skills, whereas those in regular schools tend to focus primarily on reading and writing.

- Teachers in regular schools are "freer" to create extra material and to decide on the content to be taught.

\section{Method}

This section describes the methodology used in this study, which is based on a qualitative approach. In order to understand and compare English teachers' practices in regular schools and language schools, this article aims at investigating what they think, know and believe, which is the object of study of an area called language cognition. According to Borg (2009), the study of foreign language teacher cognition was recognized as an important area of research in the mid-1990s. The main principle of this area refers to the fact that, in order to understand teachers, it is necessary to investigate the mental processes trough which they reflect upon their work. According to the author, about 40 years ago, researchers attempted to study behaviors that led to effective teaching. Nowadays, it started to become clear that we should not focus only on teachers' behavior if we intend to understand what they do, but it is necessary to understand "what they believe, what they know, their attitudes, their feelings" (Birello 2012, p. 88).

As there seems to be no public register of a research comparing teachers' beliefs on teaching English in Brazilian regular schools and language schools, the questions included in this article are mostly open. Section 2.1 describes the participants, and Section 2.2 the sampling procedures. Due to its experimental nature, this research has not selected a big sample of subjects. The aim here is to make some points evident, qualitatively, so that other works can be motivated to pursue other matters in connection, then in a quantitative manner.

\subsection{Participants}

Six subjects participated in this research: 3 teachers in regular schools and 3 teachers in private language schools. The participants were women aged between 21 and 38, graduated in Languages from Brazilian universities.

By accepting to participate in this study, all participants signed a consent form (Appendix A) and a questionnaire to register information such as name, age, level of education, occupation, experience and workload (Appendix B). We asked for permission to use the subjects' answers in the research and guaranteed the confidentiality of their identities. Therefore, the participants will be identified according to their category (regular school: RS; language school: LS) and a number from 1 to 3 , as follows:

Table 1. Participants

\begin{tabular}{|c|c|c|c|}
\hline \multicolumn{2}{|r|}{ Regular School } & \multicolumn{2}{|r|}{ Language School } \\
\hline RS 1: & $\begin{array}{l}\text { Works in a public school; } \\
\text { Experience in language course. }\end{array}$ & LS 1: & $\begin{array}{l}\text { Works in a private language school; } \\
\text { Experience in a public regular school. }\end{array}$ \\
\hline RS 2: & $\begin{array}{l}\text { Works in a private school; } \\
\text { No experience in language course. }\end{array}$ & LS 2: & $\begin{array}{l}\text { Works in a private language school; } \\
\text { No experience in regular school. }\end{array}$ \\
\hline RS 3: & $\begin{array}{l}\text { Works in a private and a public school; } \\
\text { Experience in language course. }\end{array}$ & LS 3: & $\begin{array}{l}\text { Works in a private language schol; } \\
\text { No experience in regular school. }\end{array}$ \\
\hline
\end{tabular}




\subsection{Sampling Procedures}

After agreeing to participate in the research, the subjects received a questionnaire (Appendix C) with 14 questions based on the discussion presented in 1.1 and the hypotheses in 1.2. The participants contributed with written answers to the questions, after being instructed to respond truthfully according to their work experience in regular schools or language schools. After that, the subjects sent the answers by e-mail, avoiding restraints that could be imposed on a questionnaire answered by hand at their workplace, such as lack of time, attempts at making short answers, and so on.

\section{Results}

In this section the results will be presented, following a pedagogical division according to the topics present in each group of questions. This division was not made in the original questionnaire, but it has been chosen to be done here to better show how it is possible to establish patterns to some of the answers given.

\subsection{Regular Schools X Language Schools}

The first two questions in the questionnaire aim at investigating teachers' beliefs on how regular schools and language schools are seen by students and by society in general.

Question 1 is related to the ideas presented in Barcelos (2007, p. 159), which demonstrate that students believe the language school is a place where the competence of the teachers is unquestioned, in contrast to the regular school. Five out of the six teachers agreed with the statement. Three of them believe that teachers in language schools are indeed better prepared:

Some English teachers [in regular schools] stop studying or even practicing the language. Others also feel de-motivated and give their classes without any preparation. In language schools, on the other hand, teachers are always being assessed not only on their competence but also on their performance and this aspect really makes a difference. (LS 1)

I reckon that's a popular belief in Brazil. Maybe teachers in language schools are better prepared to do their jobs because they have a strict methodology, whereas teachers in regular schools are given a syllabus, but choosing a methodology is up to them. (...) Many times, it seems as if regular schools teachers are left on their own. (LS 2)

In most schools, there are no tests to prove that you can speak English. In language schools, most of the times, you are put under a lot of tests to show that you master the language. (RS 3)

One subject agrees with the belief, but thinks that teachers in language schools are not always better prepared:

I agree - students have no confidence at all in their regular school teachers - although there are many unprepared teachers in English courses with not enough grammar or knowledge. (LS 3)

Only one participant disagrees with the statement and believes she is valued in the regular school:

In my experience, students (...) appreciate having a teacher who actually dominates the language (...). However, the schools' principals are not worried if the English teacher is qualified or not. They only care about having a teacher so that the students will not have classes until January. (RS 1)

Question 2 refers to the fact that the regular school is seen as a place where the students' expectations are not met, whereas the language school is seen as a place where one can really learn the language. All participants agree that English teaching and learning is different in these contexts, mostly because of the number of students in class, lack of discipline and motivation, as we can see in the following excerpts:

Unfortunately that is true. In regular schools the number of students is too great, so it is impossible to work all the skills in class (listening, speaking, writing and reading). Also, classes are so disturbed by the undisciplined students that everyone gives up on trying to learn English. (RS 1)

(...) in a regular school, most students don't like English and learn from obligation. In an English course students want to learn English. (RS 2)

(...) The environment of an English course favors learning, whereas in a regular school many deficiencies make learning more difficult. (RS 3)

I think language schools can cater better to students because they have smaller groups and more modern material. (LS 2)

Sometimes the teacher in a regular school has to deal with improper conditions. The most common one is a classroom with more than thirty students (...). A crowded classroom does not happen in an English course (...), which facilitates the learning process. (LS 3) 
One subject mentioned the fact that both institutions give students the opportunity to learn a new language, but they have different aims:

Whereas in language schools the aim is to develop the four language skills, in regular schools the aim is wider, in other words, learn a new culture through a different language. (LS 1)

The answers for these two questions show that most participants agree that teachers in language schools are more valued by students and that students tend to be more motivated to learn English in language schools than in regular schools. Most subjects highlight that the classroom environment is essential for the distinction between the two contexts, mainly regarding the number of students in class.

\subsection{Frustration, Benefits and Challenges}

Questions 3 and 4 refer to the benefits and challenges of teaching English in both contexts. Question 3 asks if the participants have ever felt frustrated in their teaching contexts. All the subjects gave a positive answer, and the reasons include lack of discipline, unwillingness to participate and lack of previous knowledge:

In Sapucaia, the school is in a "vila" [a place scarce in resources] and most of the students do not understand why they have to go to school, let alone learn English. So it is very frustrating to try to teach something that they cannot understand. (RS 1)

(...) students don't like English or don't understand the importance of English in their lives. (RS 2)

Many times I prepared wonderful classes that were "destroyed" by the lack of discipline - the students wouldn't behave as expected, they just played and disrespected the classmates (this mostly occurred with $5^{\text {th }}$ graders of the public school I work). (...) Another thing that frustrated me was the lack of knowledge of the $3^{\text {rd }}$ graders from High School in a public school where I used to work. They were in the last year of school and some didn't even know the verb to be. (RS 3)

At the private school where I used to work before (...) I remember I used to plan my classes very carefully and passionately, however, it didn't work as expected because the students didn't want to take part in the activities. (LS 1)

I have felt frustrated when students where in class, but not willing to learn (LS 2).

One participant mentioned the lack of infra-structure:

Only once [in a regular school]: there was no infrastructure in the school; no bathrooms and no chalk. (LS 3)

Question 4 asks about the benefits and challenges of teaching in both contexts. As to the challenges, the regular school teachers mentioned great number of students in class, lack of previous knowledge, mixed levels in the same group and motivation. The participants who teach in language schools mentioned lack of motivation and willingness to participate and catering to different students.

Regarding the benefits, the subjects who teach in regular schools mentioned the demonstration of interest and curiosity (by students), working in groups and project work:

The benefit is when some of them demonstrate interest, curiosity and end up learning a lot due to that. (RS 1)

When my student starts an English course because he/she would like to learn more. This is a benefit for me. (RS 2)

You can work in groups, you can teach English to people that probably won't study English outside of school (in the case of the public school) and this can make a difference in their lives, you can work with projects. (RS 3)

Two participants who teach at language schools did not mention the benefits in teaching in this context. One of them mentioned having state-of-the-art material and methodological and teaching support.

Question 5 aims at investigating if the students in language schools are more motivated to learn English than those in regular schools, based on the discussion presented in 1.1. It asks if the participants' students are motivated or not. One participant from regular school said that her students are not motivated (RS 2), and the other two subjects (RS 1 and RS 3) affirm that their students are usually motivated and like English:

In the public school they love English and think that it is fun to talk in English and they feel really proud when they can understand a text or a dialogue. In the private school they know how important it is to know English, they most of the time like the classes and participate. (RS 3)

I notice that they like English, but most of them are not mature enough to learn it. I try to focus on the ones who are ready, so they do not lose motivation, and I have a different look at the ones who are not, because I cannot force them to understand or be interested, no matter their reality and their background. (RS 1) 
The three participants from language schools said that their students are motivated most of the time. Therefore, the results in this research do not prove the hypothesis that students in language schools are more motivated than the ones in regular schools, as most teachers gave a positive answer.

\subsection{Teacher Development}

The next four questions refer to the teachers' beliefs on teacher development courses. Question 6 asks if having a diploma in Letras (Languages) affects their performance as teachers. The three participants who teach in private language schools gave an affirmative answer:

For sure. Today I feel much more prepared and confident to teach English than before taking Letras. (LS 1)

Yes, I believe it prepared me to face the challenges in my area. (LS 2)

Of course, and the students can tell the difference as well. Teachers graduated in Letras have much more grammar and teaching practice/background then teachers who have spent a semester abroad. (LS 3)

However, the three teachers in regular schools believe it is not the most important aspect in their performance:

I believe that having a diploma does not necessarily make you a better teacher. Some people are natural teachers, they are good with people. But taking Letras means that you studied grammar and understand better how the language works (...). (RS 1)

Having a diploma in Letras is really important but it is not the main thing. I read a lot about English grammar, vocabulary, methodology, pedagogy, I participate in courses, forums, workshops (...). (RS 3)

Question 7 asks if the participants consider their metalinguistic knowledge satisfactory. Five of them gave positive answers, and only subject LS 3 said there is a lot to improve.

Question 8 is based on the belief that teachers in language schools are more encouraged to attend continuing education courses than those in regular schools. RS 1 and RS 2 said they are encouraged, but do not have time to attend any. RS 3 said she is encouraged "by herself", as she likes studying, and the schools where she works normally wouldn't give a day off in order to participate in a course. She also said that the schools offer many courses about teaching and pedagogy, but they are directed to all kinds of teachers, not to those of any specific area.

The three participants who teach in language schools said they are encouraged to participate in those courses and think they are "essential not only for improving the teacher's competence, but also for motivating them to give even better lessons" (LS 1).

The assumption is partially confirmed, as although two participants from regular schools are encouraged, they do not attend the courses because of lack of time. Besides, according to RS 3, the courses are directed to teachers of varied subjects, differently from language schools.

Question 9 asks if the participants face situations in which they would feel more prepared if they had more courses in the area. The answers by the teachers in regular schools concern behavior and social problems, whereas the answers by the teachers in language schools refer to linguistic knowledge. RS 3 believes that courses could help her deal with behavioral problems:

I think that most of the difficult situations that I face are related to students' behavior in the public school and sometimes in the private school. Maybe some courses about the topic could help me to deal with the situation. (RS 3)

RS 1, on the other hand, believes that we cannot be taught how to deal with certain social situations, as we can see in the following passage:

No course prepares a teacher to face in a classroom the biggest problems of society. Nobody is prepared to deal with kids who suffer all kinds of abuse, do not have a well structured family, whose mother used drugs during pregnancy so the kid's cognition is forever damaged, and so on. (RS 1)

LS 1, LS 2 and LS 3 believe there is always something to learn from courses but, differently from the participants in regular schools, they mention courses on language improvement, like translation and English grammar.

\subsection{Lesson Planning and Teaching the Four Skills}

Question 10 was elaborated in order test the hypothesis that teachers in regular schools are "freer" to decide on the content to be taught. It asks how the participant chooses the content of the classes. According to RS 1, the school does not interfere: “(...$)$ especially because nobody can speak English so they cannot say if what I am 
teaching is right or not".

RS 2 says that the contents are chosen by the school according to the PCNs, and RS 3 affirms that she received a course plan from the previous teacher and was asked if she wanted to change anything. As to the public school where RS 3 also teaches, she says that the contents come from the Municipal Secretary of Education, and she can make modifications, as long as she obeys the basis.

As it was expected, the three teachers from language schools said they do not choose the content, as it is already foreseen in a Plan of Work.

Questions 11 and 12 were based on the hypothesis that classes in language schools usually integrate the four skills, whereas those in regular schools tend to focus only on reading and writing. Question 11 asks the participants to distribute proportionally how much of their classes is dedicated to the development of each of the four skills (reading, writing, speaking and listening).

As it was expected, the three participants from regular schools affirm that they dedicate at least more than $60 \%$ to reading and writing. According to RS 2, only $10 \%$ of her class is dedicated to oral expression. In the language course, on the other hand, LS 1 says it is 25\% for each skill and LS 2 and LS 3 say that they dedicate most of their class to speaking and writing come in the last position. Therefore, the hypothesis has been confirmed.

Question 12 asks which of the four skills is the most difficult to teach in their teaching context. According to the three teachers from regular schools, speaking is the most difficult skill to teach, basically because of the number of students in class:

Speaking is more difficult because there are too many students, each one with a different level due to failures, new students and so on. (RS 2)

Speaking because of the number of students in class. They feel shy, insecure to make mistakes in front of their classmates. As there are many students, while one is trying to express himself/herself in English (which sometimes takes a long time) the others start talking and the noise makes it impossible to continue with the activity. (RS 3)

As to the participants from language schools, LS 1 and LS 3 affirm that writing is the most difficult skill to teach, as students usually do not like it. According to LS 2, listening is the most difficult skill to teach because students have to understand key words and the main idea at the same time. Therefore, the procedures used to teach each of the four skills are different in the two contexts.

\subsection{Teaching Material and the Place of Grammar}

When asked to determine their level of satisfaction when it comes to teaching materials available to them, and how well they can do without them, regular school teachers mentioned computer availability, photocopies and a few resources; however, the initiative to make such resources available and useful to the students depends entirely on the teacher. When it concerned language school teachers, only one of them needed to worry about making copies for the students. The others had nothing but good words about the materials and how they related to the students' day-to-day life situations:

They are great. Very practical, easy to understand and connected to the students' reality. (LS 1)

They're great. Actually there are never any problems regarding that. (LS 2)

The book and CD are good, the exercises I prepare at home and the school makes the copies, but there are not enough computers and no internet. So the classes are in the classroom. In one of the schools there are no dictionaries, so I write the vocabulary on the board. Still, not a good thing because they do not learn how to use a dictionary. (RS 1)

When a question about grammar was presented, inquiring if they taught it explicitly or implicitly, teachers from regular schools all use explicit methods to teach English. One of them pointed out that, if the structure at hand is relatively simple, they try teaching it implicitly. Language school teachers, however, favor implicit methods of teaching, one of them mentioning that they are flexible to the needs of the students, if those require a more explicit explanation of the topic being taught:

It depends on the students. I usually teach grammar implicitly, I believe students acquire more language if they learn implicitly. (LS 3)

In both ways, however always inside a context. (LS 1)

Both. It depends on the topic being taught. Sometimes I just teach implicitly (if the topic is simple) and other times I explicit the rule in order to make it clear to all students. (RS 3) 
It seems noteworthy that, even though all of them apparently agree on the fact that implicit methods are better for students, explicit ones are the most used resources when it comes to teaching grammar.

\section{Discussion}

In this section, the main and secondary hypotheses are going to be addressed in order to better summarize and debate the findings resulted from the questionnaire.

One of the hypotheses was that teachers in language schools are more valued by students than the ones in regular schools. The results in this study support this supposition because five out of the six participants agreed on this belief. Some of them believe that teachers in language schools are really better prepared than those in regular schools, mostly because there is usually no test to prove you are proficient in the language when one starts teaching in a regular school. On the other hand, the answers show that it is possible to have very good teachers in regular schools and unprepared teachers in language schools. All participants agreed that English teaching and learning is different in the regular school and in the language school, mainly because of the number of students in class.

Another hypothesis affirmed that students tend to be more motivated to learn English in language schools than in regular schools. This hypothesis has not been supported in this study because only one regular school teacher said that her students were not motivated, and the other five teachers answered that their students are usually motivated. In order to investigate more on this assumption, perhaps a study on the students' perspective could be developed in the future, taking the same factors into consideration, so that their level of motivation could be compared.

The results in this research partially support the assumption that teachers in language schools are more encouraged to attend continuing education courses than those in regular schools. Although the teachers in regular schools are given the opportunity to participate in these courses, they mention that the courses are not specific to language teachers, contrarily to language schools. In addition, teachers in regular schools usually do not have time to attend those courses, as the workload is usually higher than in the language schools.

The hypothesis related to the teaching of the four skills has been confirmed. The skills corresponding to reading and writing take more classroom time in regular schools than in language schools. This could be a result of several factors, such as number of students in the classroom, the influence of the PCNs and the focus on admission tests for universities being in written form. Language course students seem to have a more balanced intake of English as well as work on specific abilities, which could render them more interested and feel as if they are learning more.

When it came to teaching materials, most teachers did not complain about the materials they used. However, regular school teachers did mention, when answering to other parts of the questionnaire as well, that the resources available could be better. Judging by the answers provided on this matter, it seems plausible to say that most teachers are responsible for creating, finding, choosing or adapting materials to their teaching practice. When it comes to language schools, however, the array of resources seems to be wider, and the materials available richer and in less need of adaptation or change.

As to grammar teaching, there appears to be a tendency for the language school teachers to integrate the grammar point being discussed into contextual information, or situations with which the students can relate and infer meaning from, instead of mainly focusing on the form. Regular school teachers, on the other hand, seem to use more explicit methods than language school ones, especially when introducing a new, more complex grammar topic.

There was also confirmation for the hypothesis that said regular school teachers were "freer" when it came to choosing or creating materials, or the contents to be taught. Regular schools worry mainly about fulfilling what the Brazilian laws of education subscribe as the content necessary for a student in X grade to know. However, language schools run on a much tighter schedule, they tend to cover more content in less time in comparison to regular schools. Therefore, teachers end up giving up on some of the control over materials and contents in order to abide to the course's regulations of levels and corresponding contents.

\section{Conclusion}

This study has fulfilled its aim of diagnosing main differences regarding English teaching and learning when comparing regular schools with language schools from teachers' perspective. A main hypothesis was formulated, and with its support and that of secondary hypotheses, a questionnaire was created in order to seek their potential corroboration. The questionnaire was composed of 14 key points, answered by teachers of English that work in regular schools as well as in language schools. These answers were supplied in written form by e-mail, providing the participants enough time to write as much as they wanted and reflect upon the matter. The results of their answers followed, and a discussion of the main findings was made in order to compare them to the original 
hypotheses.

By studying the participants' answers, it was possible to see that the subjects agree that teachers in language schools are usually better prepared than those in regular schools, mainly because they are more encouraged to attend continuing education courses and because they are always being assessed by a pedagogical coordinator, what does not generally happen in regular schools. In addition, there are usually no tests to prove that a teacher masters the language to enter a regular school, which is the case in language schools. Regular schools rely, therefore, on the fact that the degree in Languages being compulsory to teach at such schools implies that such degree is sufficient for a teacher to be qualified. However, it has also been approached in this study the fact that continuing education courses have been constantly promoted by the government and encouraged by institutions as one way to elevate and maintain the quality of teaching and learning of English in the country.

When it comes to freedom of methodology and materials, teachers in language schools also have a specific methodology to follow, as well as good materials available for them to use. In regular schools, on the other hand, teachers are generally given a syllabus with the contents they are supposed to teach and they have the option of choosing the methodology. Perhaps because of these reasons and the ones mentioned above, most subjects agree that teachers in language schools are more valued by students than those in regular schools.

As it was expected, all the subjects agree that there are great differences between these two contexts, such as the number of students in class, the materials available and the methodology itself. It is possible to confirm that, in language schools, the aim is to teach the four skills somewhat equally; whereas in regular schools there is great emphasis on reading and writing.

Another relevant finding is that all the participants who teach in language schools believe that having a diploma in Languages is essential because it prepared them in terms of grammar knowledge and pedagogical techniques. Teachers in regular schools, on the other hand, believe that the diploma is important, but not essential. This might be explained by the fact that the conditions in the regular school environment are not as close to the ideal as they are in private language schools. That is why teachers need a lot more than grammar and pedagogical knowledge to handle behavior and social problems in this context.

Regarding students' motivation, only one regular school teacher claimed that her students were not motivated. Both remaining regular school teachers and all language school ones affirmed that their students are motivated at least most of the time. However, the sources of such motivation cannot be ignored, nor that they are different in kind. A more detailed study on motivation from the perspective of the students would be complementary to this study, also in the way that it would provide a basis of comparison between what the students actually feel and what is perceived by their teachers in relation to the classes and the language itself. The hypothesis that language school students were more motivated than regular school ones was largely based on the fact that students feel motivated to seek language schools and, consequently, are more motivated about them in class as well, being that due to more confidence in the teachers' abilities or knowledge of the language, the school's methodology, the overall proficiency rate of students that finish the course in such schools, and so on. Nevertheless, the motivation affirmed existent in regular school students seems to be rooted in the fact that they genuinely like the language, and that is most definitely a positive aspect that should be taken into consideration.

Considering what has been the focus of this study, it seems reasonable to say that the teaching and learning of English in Brazil should be addressed by more studies of comparative nature, regarding especially regular schools and language schools. In the past, studies comparing private and public regular schools were the main focus of such comparisons, searching for pluses and minuses between a government institution and a private one. However, the biggest gap when it comes to teaching and learning of English seems to be found not in terms of the dichotomy public X private regular school, but in the regular school X language school one.

Finally, more studies of quantitative character are necessary in order to better assess the abyss that stands between regular schools and language schools in terms of teaching of English. This study has proven itself a pioneer one, for it made more evident such differences, and perhaps pointed the way to more detailed and closer analyses of what could be done in order to make English teaching in Brazil more coherent and effective in general.

\section{References}

Barcelos, A. M. F. (2007). Narrativas, crenças e experiências de aprender inglês. Revista Brasileira de Lingüistica Aplicada, 7(2), 145-175.

Birello, M. (2012). Teacher Cognition and Language Teacher Education: beliefs and practices. A convers ation with Simon Borg. Ballaterra Journal of Teaching \& Learning Language \& Literature, 5(2), 8 
8-94. Retrieved from http://ddd.uab.cat/pub/beljoutealealanlit/beljoutealealanlit_a2012m5-6v5n2/jt13_a20 12m5-6v5n2p88.pdf

Brasil. (1998). Secretaria de Educação. Parâmetros Curriculares Nacionais para a Língua Estrangeira, Ensino Fundamental. Brasília. Retrieved from http://portal.mec.gov.br/seb/arquivos/pdf/pcn_estrangeira.pdf

Brasil. (2000). Secretaria de Educação. Parâmetros Curriculares Nacionais para a Língua Estrangeira, Ensino Médio. Brasília. Retrieved from: http://portal.mec.gov.br/seb/arquivos/pdf/14_24.pdf

Borg, S. (2009). Introducing language teacher cognition. Retrieved from http://www.education.leeds.ac.uk/ research/files/145.pdf

Coelho, H. S. H. (2005). É possivel aprender inglês na escola? Crenças de professores sobre o ensino de inglês em escolas públicas. Master's thesis. Faculdade de Letras da UFMG, Belo Horizonte, Minas Gerais. Retrieved from http://www.bibliotecadigital.ufmg.br/dspace/bitstream/1843/ALDR-6ACG69/1/disserta_o_pdf_hilda_coel ho.pdf

Crystal, D. (2003). The Cambridge Encyclopedia of the English Language (2nd ed.). New York: Cambridge University Press (499 pages).

Felix (2005). Crenças de duas professoras de uma escola pública sobre o processo de aprender língua estrangeira. In Almeida Filho, J. C. P. O., professor de língua estrangeira em formação (2nd ed.). Campinas, SP: Pontes.

Fontes, P. (2011). Mercado aquecido para os professores de inglês com a valorização do idioma. Retrieved from http://jornal.ofluminense.com.br/editorias/empregos-e-negocios/mercado-aquecido-para-os-professores-de-i ngles

Fragozo, C. S. (2011). Benefits and challenges of teaching English in Brazilian regular schools. Brazilian English Language Teaching Journal (BELT), 2(1), 17-26.

Jenkins, J. (2003). World Englishes. A resource book for students. Routledge English language introductions. London and New York.

Lopes, M. C., \& Raquel C. M. de. (2007). Formação do Professor de Inglês: Educação Infantil e Ensino Fundamental ( $1^{\mathrm{a}}$ a $4^{\mathrm{a}}$ séries). Retrieved from http://www.cce.ufsc.br/ clafpl/55\%20_Monica_e_Raquel.pdf

Miccoli, L. (2007). Experiências de professores no ensino de língua inglesa: uma categorização com implicações para o ensino e a pesquisa. Linguagem \& Ensino, 10(1), 47-86. Retrieved from http://www.rle.ucpel.tche.br/index.php/rle/article/viewFile/155/122

Perin, J. O. R. (2003). Ensino/aprendizagem de inglês em escolas públicas: um estudo etnográfico. Acta Scientiarum: human and social sciences, 25(1), 113-118.

Schenini, F. (2008). Programas de formação continuada podem ajudar a melhorar o nível dos professores de inglês. Jornal do Professor, $37 . \quad$ Retrieved from http://portaldoprofessor.mec.gov.br/conteudoJornal.html?idConteudo=1091

Tonelli, J. R. A., \& Cristóvão, V. L. L. (2010). O papel dos cursos de Letras na formação de professo res de inglês para crianças. Caleidoscópio, 8(1), 65-76. Retrieved from http://www.unisinos.br/revista s/index.php/calidoscopio/article/view/159

Villani, F. L. (2008). O efeito das crenças dos professores de língua inglesa na escola pública. Revista Múltiplas Leituras, 1(2), 141-155. Retrieved from http://www.metodista.br/ppc/multiplas-leituras/multip las-leituras-02/o-efeito-das-crencas-dos-professores-de-lingua-inglesa-na-escola-publica/ 


\section{Appendix A}

\section{PONTIFÍCIA UNIVERSIDADE CATÓLICA DO RIO GRANDE DO SUL PROGRAMA DE PÓS-GRADUAÇÃO EM LETRAS}

Dear participant,

You are invited to take part in a scientific study led by Carina Silva Fragozo (PUC-RS) and Mônica Deitos Stedile Monawar (PUC-RS).

This research aims at investigating teachers' beliefs on regular schools and privatelanguage schools in Brazil. The study is based on a qualitative approach, and your task is to contribute with written answers to fifteen questions. Your answers will be confidential and used only in this study. Your identity will also remain confidential.

Participation in the study is completely voluntary. If you decide to take part in the study, you have the right to cancel your participation at any time, without any consequences. You also have the right not to answer any questions you don't want to answer, and still continue participating in the study.

\section{CONSENT FOR RESEARCH STUDY}

By giving my consent I confirm my voluntary participation in this research. I have read and understood the research description above, and confirm that I have received sufficient information on the study.

Name

Signature

Date:

\section{Appendix B}

\section{PONTIFÍCIA UNIVERSIDADE CATÓLICA DO RIO GRANDE DO SUL PROGRAMA DE PÓS-GRADUAÇÃO EM LETRAS}

This quick questionnaire aims at registering relevant data about the participants. Thank you for the participation!

6) Name:

2) Age:

3) Level of education: ( ) Graduation in Letras. Year:

( ) Specialization Course. Which one?

( ) Master's Degree. Year: 
( ) PhD. Year:

4) At present, teaches in: ( ) regular school. Private or public?

( ) language course

( ) both

5) Has experience in: ( ) regular school. Private or public?

( ) language course

6) How many hours do you work a week? Please, specify.

\section{Appendix C}

\section{QUESTIONNAIRE}

\section{Please, answer the questions according to your experience and your beliefs.}

1) Read the following excerpt:

Sometimes I had discussions with teachers [in the regular school] because they used to teach wrong things and I was the only one who knew it was wrong. It was so different from the English course. (Barcelos, 2007)

According to the passage, the language course is a place where the competence of the teachers is unquestioned, in contrast to the regular school. Do you agree? Have you ever felt this in your classes?

2) Research shows that the regular school is seen as a place where the students' expectations are not met, whereas the language course is seen as an investment, as a place where you can really learn the language. What do you think?

3) Have you ever felt frustrated in your teaching context? Why?

4) What are the main challenges that you face in this context? And the benefits?

5) Do you think your students are motivated to learn English?

6) Do you think that having a diploma in Letras affects your performance as an English teacher?

7) Do you consider your metalinguistic knowledge satisfactory?

8) Are you encouraged to attend continuing education courses in English? Why wouldn't you take this kind of course?

9) Do you face situations in which you feel that you would be more prepared if you had more courses in the area?

10) How do you choose the content to be taught? How does the school interfere?

11) Distributing proportionally, how much of your class is dedicated to the development of: (a) reading, (b) writing, (c) oral expression, (d) listening?

12) Which of the four skills (reading, writing, listening, speaking) is the most difficult to teach your students?

13) How do you evaluate teaching material (books, CDs, photocopies, technological resources, dictionaries, etc.) offered by the school? If it is not available, how do you handle it?

14) How do you teach grammar? Implicitly or explicitly? 